\title{
$\mathrm{Ag}$ 添加した Al-Mg-Si 合金における中間相の HRTEM 観察
}

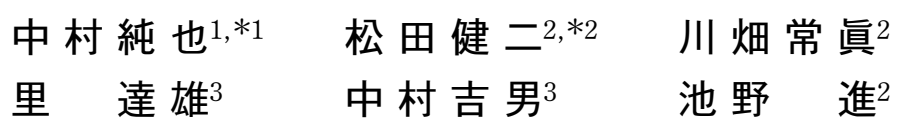

1 富山大学大学院理工学教育部

2 富山大学大学院理工学研究部

3 東京工業大学大学院理工学研究科

J. Japan Inst. Metals, Vol. 75, No. 3 (2011), pp. 179-187 (C) 2011 The Japan Institute of Metals

\section{HRTEM Observation of Intermediate Precipitates in Al-Mg-Si Alloys Containing Ag}

Junya Nakamura ${ }^{1, * 1}$, Kenji Matsuda ${ }^{2, * 2}$, Tokimasa Kawabata², Tatsuo Sato ${ }^{3}$, Yoshio Nakamura ${ }^{3}$ and Susumu Ikeno ${ }^{2}$

${ }^{1}$ Graduate School of Science and Engineering for Education, University of Toyama, Toyama 930-8555

${ }^{2}$ Graduate School of Science and Engineering for Research, University of Toyama, Toyama 930-8555

${ }^{3}$ Graduate School of Science and Engineering, Tokyo Institute of Technology, Tokyo 152-0033

This study uses high-resolution transmission electron microscopy (HRTEM), selected-area electron diffraction (SAED), and energy-dispersive $\mathrm{X}$-ray spectroscopy to identify the crystal structure of a metastable phase in a Ag-added Al-Mg-Si alloy, which we compared with the crystal structure of the $\beta^{\prime}$-phase in Al-Mg-Si alloys without Ag. SAED patterns and HRTEM images of the $\beta^{\prime}$-phase in the $\mathrm{Ag}$-added $\mathrm{Al}-\mathrm{Mg}-\mathrm{Si}$ alloy were similar to those of the $\beta^{\prime}$-phase in the $\mathrm{Al}-\mathrm{Mg}$-Si alloy without $\mathrm{Ag}$. However, the lattice spacings were modified by the substitution of $\mathrm{Ag}$ into the $\beta^{\prime}$-phase. Analyses of the obtained HRTEM images and SAED patterns revealed that the $\beta^{\prime}$-phase has a more complex crystal lattice that consists of large $(0.69 \mathrm{~nm})$ and small $(0.24 \mathrm{~nm})$ hexagons. Discrete variational $(\mathrm{DV}-\mathrm{X} \alpha)$ calculations were applied to the small cluster of the $\beta^{\prime}-$ phase. The results indicate that it should be possible to substitute silver in the $\beta^{\prime}$-phase.

(Received September 30, 2010; Accepted December 15, 2010)

Keywords: aluminum-magnesium-silicon alloy, silver addition, precipitation, high resolution transmission electron microscopy, selected area electron diffraction pattern, discrete variational $(D V-X \alpha)$ method

\section{1. 緒言}

時効硬化型 $\mathrm{Al}$ 合金である $\mathrm{Al}-\mathrm{Mg}-\mathrm{Si}$ 合金に対する $\mathrm{Cu} の$ 添加は, 時効による硬化を促進し, 析出物の数密度を増加さ せることが知られている11. また， $\mathrm{Q}^{\prime}$ るいは $\mathrm{Q}$ 相といった $\mathrm{AlMgSiCu}$ 系化合物の析出を伴うことも知られている. 例え ば Chakrabarti らによると, $\mathrm{Al}-\mathrm{Mg}-\mathrm{Si}-\mathrm{Cu}$ 合金の強化は $\mathrm{Al}-\mathrm{Mg}-\mathrm{Si}$ 合金で一般に知られている $\beta^{\prime \prime}$ 相に加え, ラス状 の $\mathrm{Q}^{\prime}$ 相の影響によると報告している ${ }^{2-5)}$. また, Caylon らは, 6000 系 $\mathrm{Al}$ 合金と 2000 系 $\mathrm{Al}$ 合金の時効析出過程を高分解 能透過型電子顕微鏡 (HRTEM) 観察を行って比較し, $\beta^{\prime}$ 相 から $\mathrm{B}^{\prime}$ 相への遷移を $\mathrm{Q}^{\prime}$ 相と対比させて報告した Massardier らは $\mathrm{Al}-\mathrm{Mg}-\mathrm{Si}$ 合金で観察される典型的な $\beta^{\prime}$ 相 を $\beta_{\mathrm{I}}^{\prime}$ 相, $\mathrm{Al}-\mathrm{Mg}-\mathrm{Si}-\mathrm{Cu}$ 合金で見られる $\mathrm{Q}^{\prime}$ 相を $\beta_{\text {II }}^{\prime}$ として示 $し \beta_{\mathrm{I}}^{\prime} \rightarrow \beta_{\mathrm{II}}^{\prime}$ と $\beta_{\mathrm{II}}^{\prime} \rightarrow \beta$ の遷移を示した ${ }^{9)}$. また, Marioara ら は Si によって構成されるネットワークに注目し， Al- Mg-

\footnotetext{
*1 富山大学大学院生 (Graduate Student, University of Toyama)

*2 Corresponding author, E-mail: matsuda@eng.u-toyama.ac.jp
}

$\mathrm{Si}-(\mathrm{Cu})$ 合金に析出するすべての準安定相が結晶構造的に関 係があることを示した ${ }^{10)}$. このように $\mathrm{Cu}$ の添加は 6000 系 $\mathrm{A} 1$ 合金の $\beta^{\prime}$ 相や $\mathrm{Q}^{\prime}$ 相などいわゆる中間相の結晶構造的な遷 移に対して影響を与えると考えられる.

一方, Polmear らは Ag を数種類の $\mathrm{Al}$ 合金に添加し, 特 に Mg を含む合金系において $393 \mathrm{~K}$ から $493 \mathrm{~K}$ の中間温度 領域で大きな影響を与えることを示し, $\mathrm{Ag}$ がこれらの析出 物の核生成速度を加速すると報告している．その中で $\mathrm{Al}-$ $\mathrm{Mg}-\mathrm{Si}$ 系合金では 6061 合金の $473 \mathrm{~K}$ 付近の時効でもっとも 影響を与え, 時効の速度と時効硬化量が上がると報告してい る11). また，馬場と高島によると， $\mathrm{Al}-1.0$ at $\% \mathrm{Mg}_{2} \mathrm{Si}$ 合金 を $448 \mathrm{~K}$ で時効した場合, $0.1 \mathrm{at} \%$ Ag 添加は, 時効硬化 を助長するとしている12)。前口らは，0.4 mass\% Ag 添加し た $\mathrm{Al}-1.3$ mass $\% \mathrm{Mg}_{2} \mathrm{Si}$ 合金の $453 \mathrm{~K}$ での時効において硬 化速度とピーク硬さが増大すると報告しており，その理由と して $\beta^{\prime \prime}$ 相が高密・微細化し, その析出量が増加するためで あるとしている13).

本研究室でも $\mathrm{Cu}$ あるいは $\mathrm{Ag}$ 添加した $\mathrm{Al}-1.0$ mass \% $\mathrm{Mg}_{2} \mathrm{Si}$ 合金において, 引張試験での均一伸びの増加と, 時 
効初期に抢ける硬さの増加率が増加すること，また DSCを 用いた析出過程に関する報告をしている14,15)。 また, 粒界析 出物として $\mathrm{Cu}$ 添加した $\mathrm{Al}-\mathrm{Mg}-\mathrm{Si}$ 合金に見られる $\mathrm{AlMgSiCu} 4$ 元系化合物である $\mathrm{Q}^{\prime}$ 相あるいは $\mathrm{Q}$ 相と類似し た $\mathrm{AlMgSiAg}$ 系の金属間化合物の存在も見出している ${ }^{16)}$. このように, $\mathrm{Al}-\mathrm{Mg}-\mathrm{Si}$ 合金に対する $\mathrm{Ag}$ の添加は $\mathrm{Cu}$ 添加 と類似の挙動が報告されているが，析出物，とくに中間相の 結晶構造を詳細に調べた報告はない。前報において, 著者ら は添加された $\mathrm{Ag}$ が $\beta^{\prime}$ 相中に構成元素として含まれる可能性 を指摘した ${ }^{17)}$ 。そこで本報告では， $\mathrm{Al}-\mathrm{Mg}-\mathrm{Si}$ 合金の中間相 のより詳細な構造を明らかにするために，Al-0.94 mass\% $\mathrm{Mg}_{2} \mathrm{Si}-0.55$ mass\% $\mathrm{Ag}$ 合金を時効したときに母相中に析出 する棒状の中間相をさまざまな方向から HRTEM を用いて 観察を行い, HRTEM 像と制限視野電子回折 (SAED) 図形 から析出物の結晶構造について詳細に調査した結果を報告す る.

\section{2. 実 験 方 法}

実験に使用した $\mathrm{Al}-0.94$ mass \% $\mathrm{Mg}_{2} \mathrm{Si}-0.55$ mass \% Ag 合金は，99.99\% Al, 99.9\% Mg, Si そして Ag 地金を使用し て大気中にて溶製した。比較のために，Ag を含まない $\mathrm{Al}-$ 1.0 mass $\% \mathrm{Mg}_{2} \mathrm{Si}$ 合金も作製した。 以後，前者を $\mathrm{Ag}$ 添加 合金，後者を基合金と称する，溶製した試料は鋳造組織を取 り除くため均質化処理後に熱間圧延し, 冷間圧延にて 0.2 $\mathrm{mm}$ の薄板にした．薄板は機械研磨にて表面を鏡面にした 後, 熱処理は $848 \mathrm{~K}$ の大気炉で $3.6 \mathrm{ks}$ の溶体化処理後, 水 水中に焼き入れ，そして $523 \mathrm{~K}$ の塩浴中で時効処理を施し た。時効した試料は過塩素酸 : エタノール $=1: 9$ と, 硝 酸 : メタノール $=1: 3$ の 2 種類の溶液を用いた電解研磨法 によって TEM 観察用の薄膜試料とした。組織観察は透過型 電子顕微鏡トプコン製 EM-002B を加速電圧 $120 \mathrm{kV}$ で，日 本電子製 $4010 \mathrm{~T}$ を $400 \mathrm{kV}$ で用いて行った。 それぞれの電 子顕微鏡に付属のエネルギー分散型 $\mathrm{X}$ 線分光分析器 (EDS) により化学組成分析を行った. SAED 図形のシミュレーシ
ョンは Crystal Systems 社の Crystal studio version 8.0 Enterprise を用いて行い, HRTEM シミュレーションはマ ルチスライス法を用いて行った.

\section{3. 実 験 結 果}

Fig. 1(a)に Ag 添加合金を $523 \mathrm{~K}$ で $120 \mathrm{ks}$ まで時効した 試料の TEM 明視野像を示す。観察している母相の面方位は アルミニウムの $[001]$ 方向に平行で, 棒状析出物の長手方向 が母相の $[100]$ 抢よ゙ $[010]$ 方向に平行に配列している。 た黒い粒状のコントラストは，観察方向に対して平行で，母 相の[001]方向に配列する棒状析出物の長手方向に垂直な断 面である. 以下，これを析出物断面と称する. 基本的にはこ のような棒状析出物が観察されるの久で，例えば $\mathrm{Al}-\mathrm{Ag}$ 合 金に見られるような板状 $\gamma^{\prime}$ 相などは観察されなかった．Fig. 1(b)は，各時効時間まで時効した試料を HRTEM 観察し て，そこに存在した析出物断面を HRTEM 像における特徵 からいくつかのタイプに分類して，各時効時間において観察 された析出物の総数を分母として，それぞれの析出物の数を 除して析出物の存在割合として示した結果である. タイプ分 けは既報に基づき ${ }^{18)}$ ， HRTEM 像中の輝点の配列から，周 期性のみられないランダムタイプの析出物, 平行四辺形タイ プの析出物，そして $\beta^{\prime}$ 相とした。図中には○印で示した硬 さ变化曲線も併記した。この時効温度では，時効の初期にお いてすでに平行四辺形タイプが多く存在していた． $473 \mathrm{~K}$ 以 下の温度において時効の初期生成物として顕著に観察される ランダムタイプは，この温度では少なく，時効の進行ととも に減少した．平行四辺形タイプはランダムタイプとは逆に， 時効の進行とともに増加するが，0.48 ks でピークを迎え， その後減少した. 平行四辺形タイプの析出物が減少する時期 とほぼ同時に， $\beta^{\prime}$ 相の存在割合が急激に増加し， $12 \mathrm{ks}$ でほ ぼ $100 \%$ となった．本実験においては $\beta^{\prime}$ 相に注目するため, $\beta^{\prime}$ 相が確実に存在する $120 \mathrm{ks}$ の時効時間に固定して, 以下 の実験を行った。

Fig. 2 (a)に， $523 \mathrm{~K}$ で $120 \mathrm{ks}$ 時効した試料中に存在した

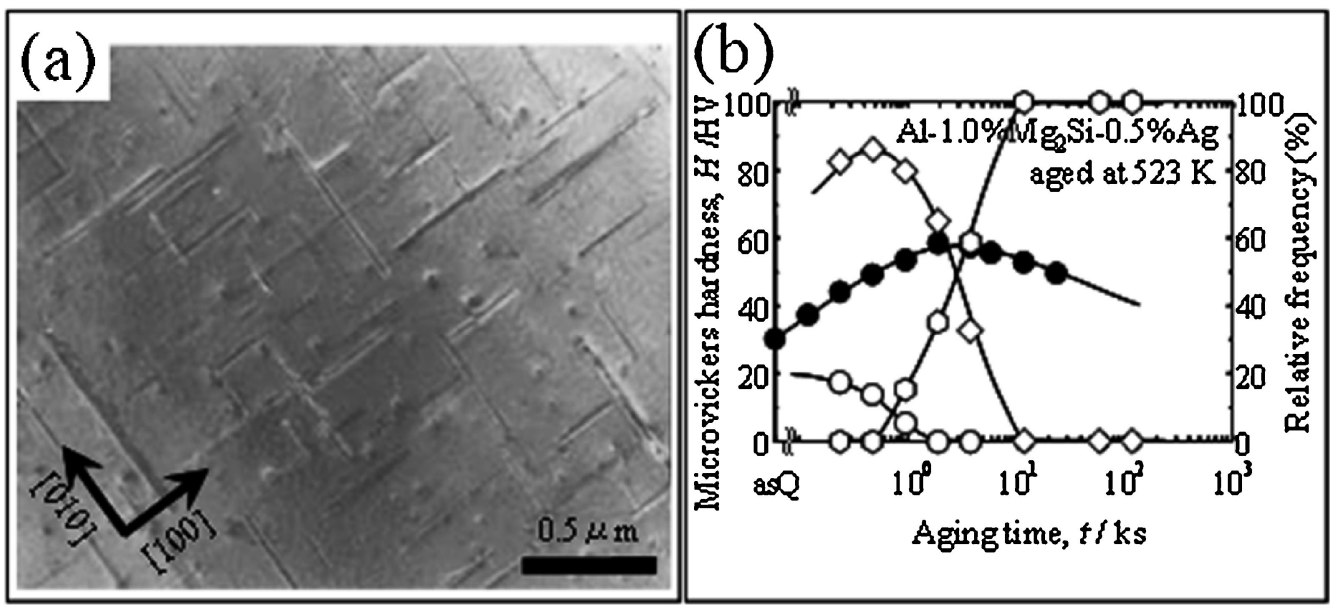

Fig. 1 (a) Bright-field TEM image of $\mathrm{Al}-1.0$ mass $\% \mathrm{Mg}_{2} \mathrm{Si}-0.5$ mass $\% \mathrm{Ag}$ (Ag-added) alloy aged at $523 \mathrm{~K}$ for $120 \mathrm{ks}$. (b) Changes in the relative frequencies for each type of precipitate in the $\mathrm{Ag}$-added alloy aged at $523 \mathrm{~K}$. $\mathrm{O}$ : hardness curve; $\bigcirc$ : random; $\diamond$ : parallelogram type; $\square: \beta^{\prime}$ phase. 

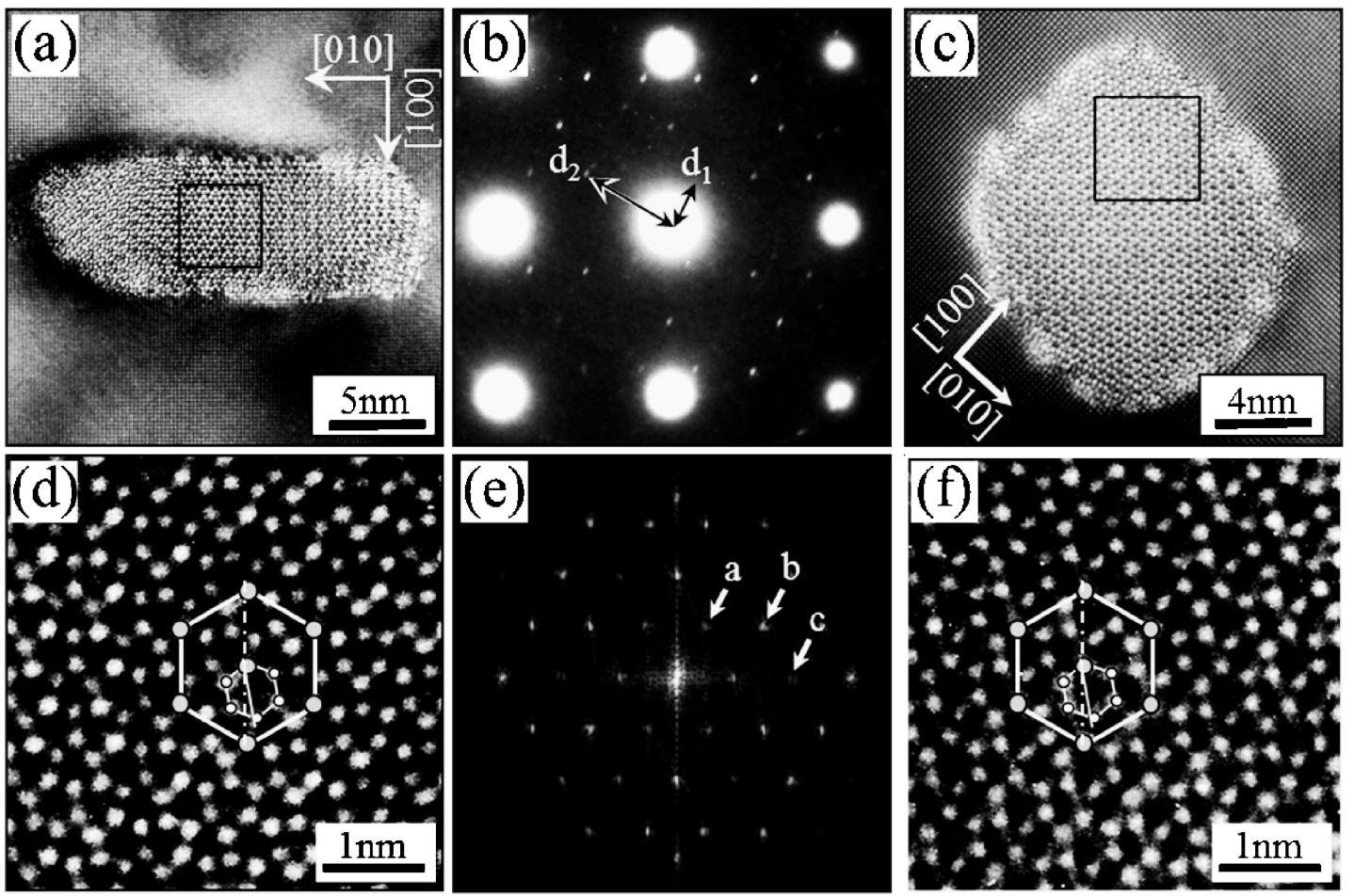

Fig. 2 Transmission electron micrographs: (a) high-resolution image and (b) SAED pattern of a rod section of Ag-added alloy aged at $523 \mathrm{~K}$ for $120 \mathrm{ks}$, (c) high-resolution image of the base alloy aged at $523 \mathrm{~K}$ for $12 \mathrm{ks}$, (d) magnified image of square in (a), (e) FFT power spectrum obtained from (a), and (f) magnified image from square in (c).

析出物断面より得られた HRTEM 像の一例を示す。析出物 断面の形状は楕円形をしており，長径は母相の[010]方向に 伸びていた．析出物の内部には一辺の間隔が約 $0.69 \mathrm{~nm} の$ 正六角形の輝点の配列が観察され，これは $\mathrm{Ag}$ を含まない基 合金において観察される $\beta^{\prime}$ 相と類似した特徵であった. Fig. 2(b)に析出物断面より得られた SAED 図形を示す。この SAED 図形中には，A1 母相からの正方形の配列を示す回折 斑点と析出物からの正六角形の配列を示す回折斑点が同時に 現れている。 また，Fig. $2(\mathrm{~b})$ の図中に示した $d_{1}, d_{2}$ に相当 する 000 透過斑点とその最近接の回折斑点，および第二近 接の回折斑点との距離から計算された面間隔 $d_{1}$ と $d_{2}$ はそれ ぞれ $0.59 \mathrm{~nm}$ と $0.34 \mathrm{~nm}$ であった.これらの面間隔は析出 物の単位胞を $a=0.69 \mathrm{~nm}$ の六方晶であると仮定すると，そ れぞれ $\{1 \overline{1} 00\}$ 面と $\{11 \overline{2} 0\}$ 面の間隔に対応すると考えられ る. 著者らのこれまでの研究では, 基合金で観察される $\beta^{\prime}$ 相は $a=0.705 \mathrm{~nm}, c=0.405 \mathrm{~nm}$ の六方晶であると考えてお り19)，基合金中のそれから得られた $\{1 \overline{1} 00\}$ 面と $\{11 \overline{2} 0\}$ 面に 相当する SAED 図形上での間隔 $d_{1}$ と $d_{2}$ は，それぞれ約 $0.61 \mathrm{~nm}$ と約 $0.35 \mathrm{~nm}$ であり, 今回の $\mathrm{Ag}$ 添加合金では, そ れらの面間隔が小さくなっていることがわかった。前報17) に打いて， $\beta^{\prime}$ 相の結晶格子が $\mathrm{Ag}$ 添加合金では小さくなって いることを報告したが，この析出物に拈いても同じであるこ とが確認された。図は省略したが，棒状析出物の長手方向に 垂直な側面から得た SEAD 図形の解析結果では，析出物のc 軸は $\mathrm{Al}$ 母相の格子定数である $a=0.405 \mathrm{~nm}$ と同じであるこ とを確認している. Fig. 2(d)は，Fig. 2(a)の HRTEM 像に 沶いて，四角で囲った部分を拡大した像である。この析出物 の内部に見られる輝点配列は，Fig. $2(\mathrm{~d})$ 中に示したよう
に, 一辺が約 $0.69 \mathrm{~nm}$ の大きい正六角形の配列と, 一辺が 約 $0.24 \mathrm{~nm}$ の小さな正六角形の配列が見られた. 小さい正 六角形は，大きい正六角形の各頂点を回転軸として，左回り に約 $10^{\circ}$ 回転しているように観察された。そこで $\mathrm{Ag}$ を含ま

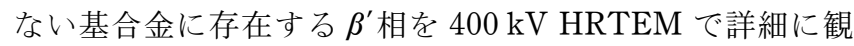
察し直した結果を Fig. 2(c)に示した. Fig. 2(f)は Fig. 2 (c) の HRTEM 像中に四角で示した部分を拡大したが，Fig. 2 (d) と同様の特徵，つまり基合金に見られる $\beta^{\prime}$ 相においても 大小の正六角形の回転関係が確認できた。従ってこのような HRTEM 像に抢ける特徵は Ag 添加によって現れたもので はなく $\beta^{\prime}$ 相が本質的に持っている構造であると考えられる. Fig. 2 (e)に Fig. 2(d)の HRTEM 像を高速フーリエ変換し て得られたパワースペクトル像を示す。このパワースペクト ル像には, 中心のスポットから $\mathrm{a}$ と b で示した最近接と第 二近接のスポットに比べて， c で示した第三近接のスポット が弱くなるという，Fig. 2(b)に示した実際のSAED 図形と 同様の特徵が見られた.

Fig. 3 には，同じ時効条件の試料中に存在し，Fig. 2(b) と同じ SAED 図形を示した $\beta^{\prime}$ 相の析出物断面より得られた HRTEM 像とそれらから得られたパワースペクトル像を示 す。それぞれの一部を拡大した Fig. 3(e)〜 (h) では，輝点配 列に異なるコントラストが観察され，さらにそれらから得ら れたパワースペクトル像も, Fig. 3(i)〜 (1)に示したよう に，得られたスポットの強度にも差が見られた。一般に HRTEM 像における格子縞のコントラストは，撮影時の試 料厚さやフォーカス条件の違いから变化することが知られて いる20)。そこで SEAD 図形と同じ強度を示すパワースペク トル像の得られる HRTEM 像を用いることで，統一した撮 


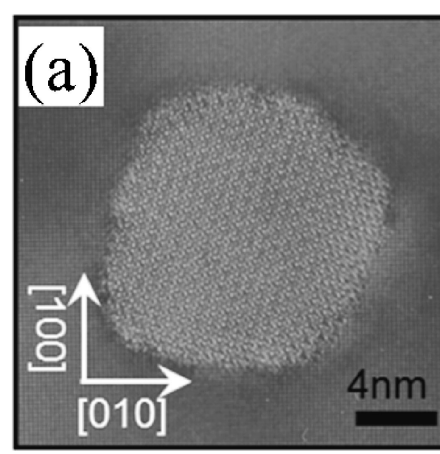

\section{(b)}
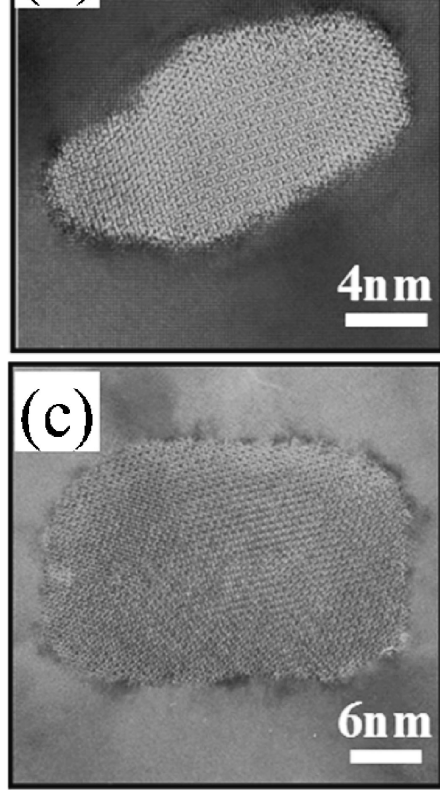

\section{(d)}

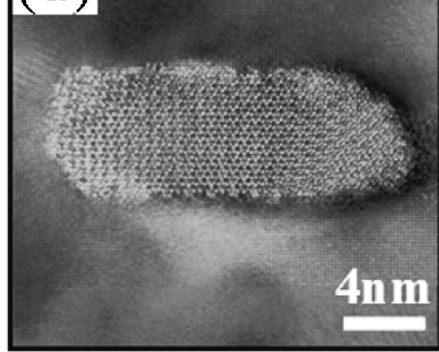

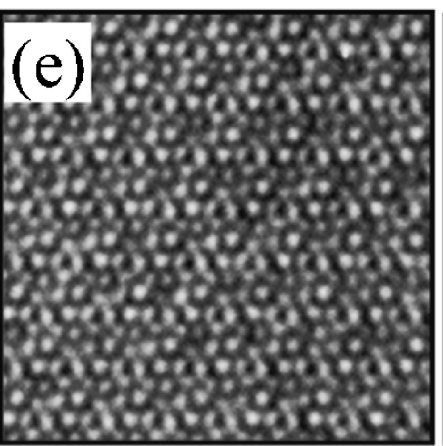
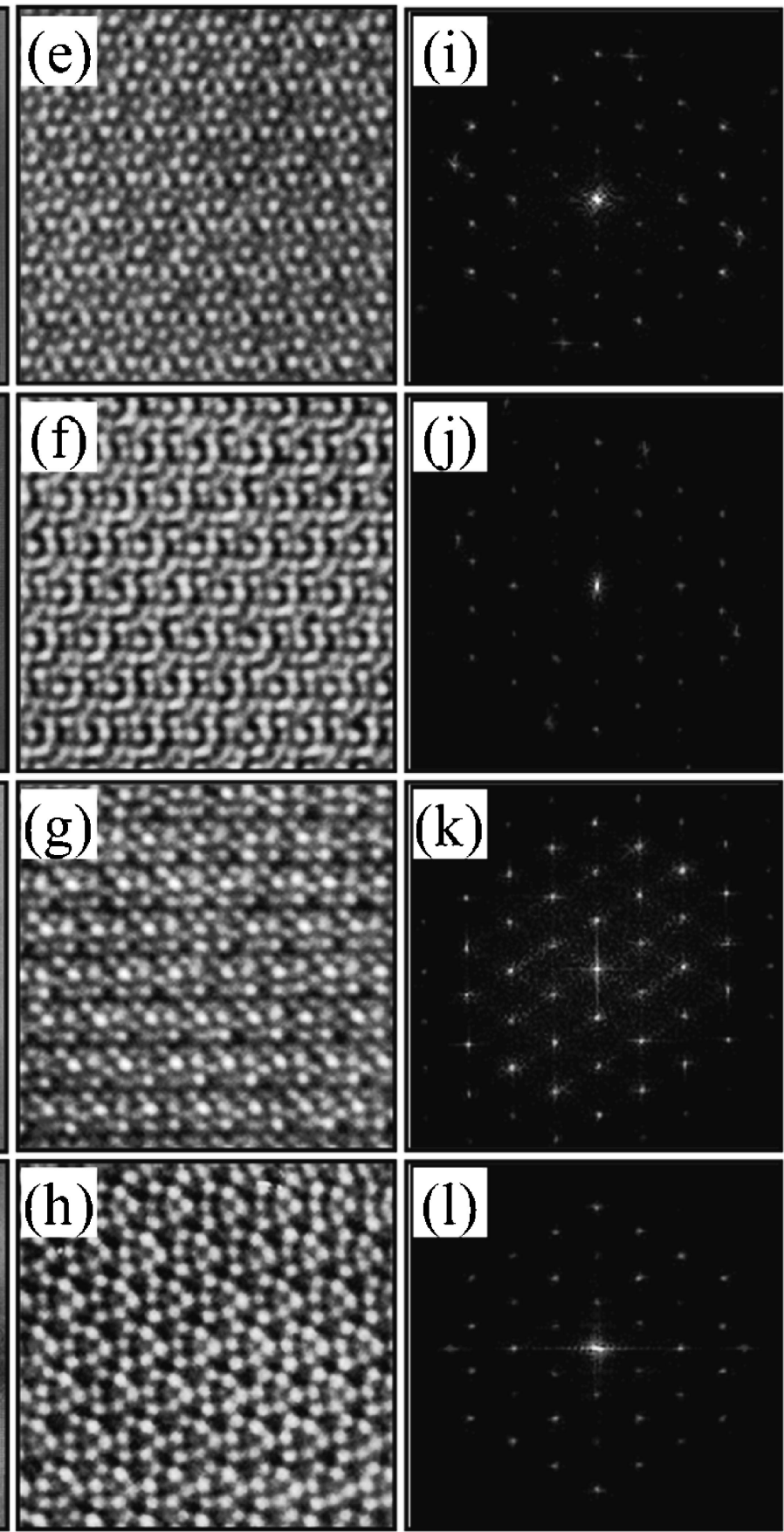

Fig. 3 (a)-(d) HRTEM images of rod sections of all the $\beta^{\prime}$ phases. (e) $-(h)$ enlarged images of precipitate in (a) $-(d)$, and (i) $-(1)$ FFT power spectra from all the HRTEM images.

影条件での結晶格子の検討ができると考え, Fig. 2(c)を以 後の検討に使用することにした.

Fig. 4(a)には $\beta^{\prime}$ 相より得られた EDS 分析の結果を示す. プロファイル中に見られる $\mathrm{Al}$ のピークは析出物周囲の $\mathrm{Al}$ 母相の影響によるものと考えられたので, $\mathrm{Al}$ 母相の影響を 除外するために, EDS 分析結果に抢ける $\mathrm{Al}$ 母相の濃度を 0

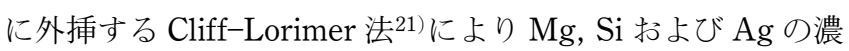
度を求めた。その結果を時効時間に対してプロットしたもの を Fig. 4(b)に示す. 時效時間が長くなるにつれて $\beta^{\prime}$ 相の化 学組成は, 49.7 at\% $\mathrm{Mg}, 34.5$ at\% $\mathrm{Si}$ そして 15.8 at\% $\mathrm{Al}$ と, 約 $\mathrm{Mg}: \mathrm{Si}: \mathrm{Ag}=3: 2: 1$ に近い值に収束するようであ り, $\beta^{\prime}$ 相に $\mathrm{Ag}$ が含まれると考えられた。

\section{4. 考察}

$\beta^{\prime}$ 相の結晶構造について，著者らは Fig. 5(a)に示したよ うなモデルを以前に提案した ${ }^{19}$ ）。前報に扔いてはJacobs の 報告22)を基本にしてできるだけ単純な最密六方晶を用いて 考察した. 白球が $\mathrm{Mg}$, 黒球が $\mathrm{Si}$ 原子を示して抢り, 一辺 が $0.705 \mathrm{~nm}$ の大きい正六角形格子と, 黒球で作られる一辺 が $0.407 \mathrm{~nm}$ の正六角形が同一結晶面上に存在し, その他の 白球は $c$ 軸方向に $1 / 2$ ずれている. さらにこの格子を 2 次元 投影すると, 白球と黒球により一辺が $0.235 \mathrm{~nm}$ の正六角形 副格子も形成されることが分かる．そこで，この格子を $\beta^{\prime}$ 

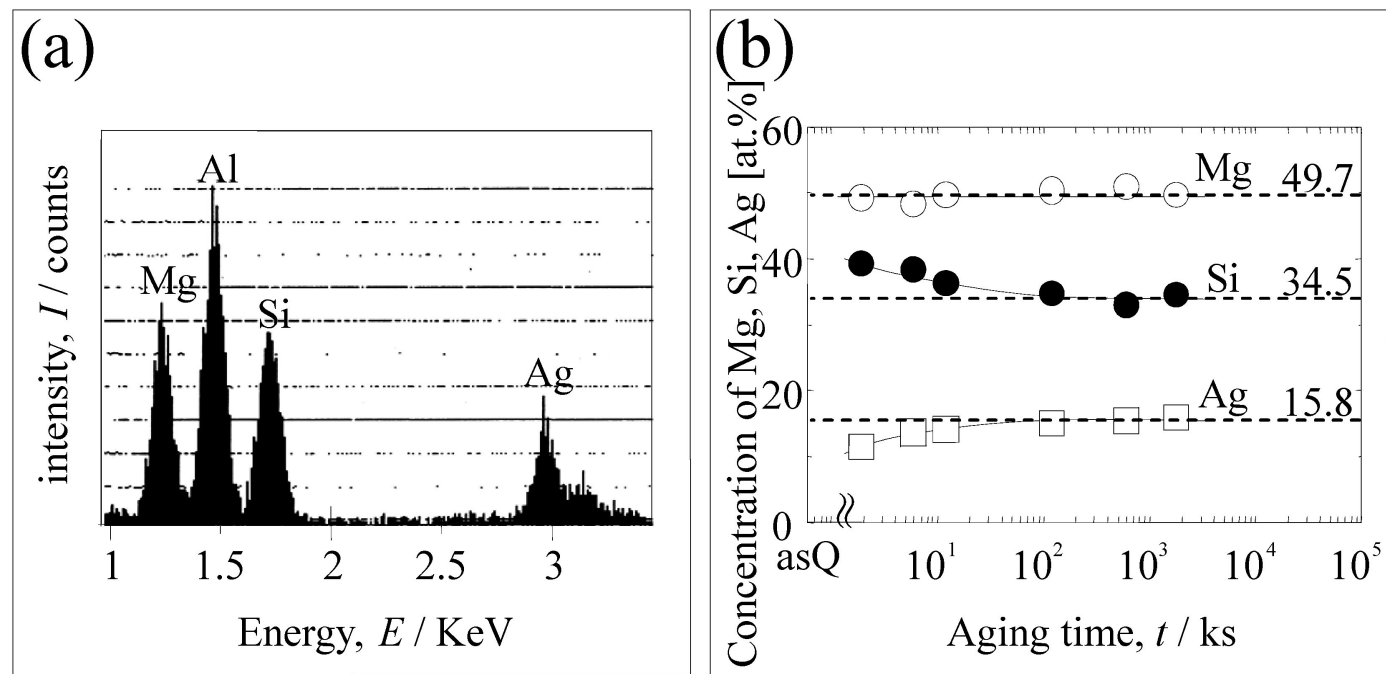

Fig. 4 EDS analysis results for the $\beta^{\prime}$ phase. (a) EDS spectrum and (b) quantitative analysis by Cliff-Lorimer method ${ }^{21)}$.
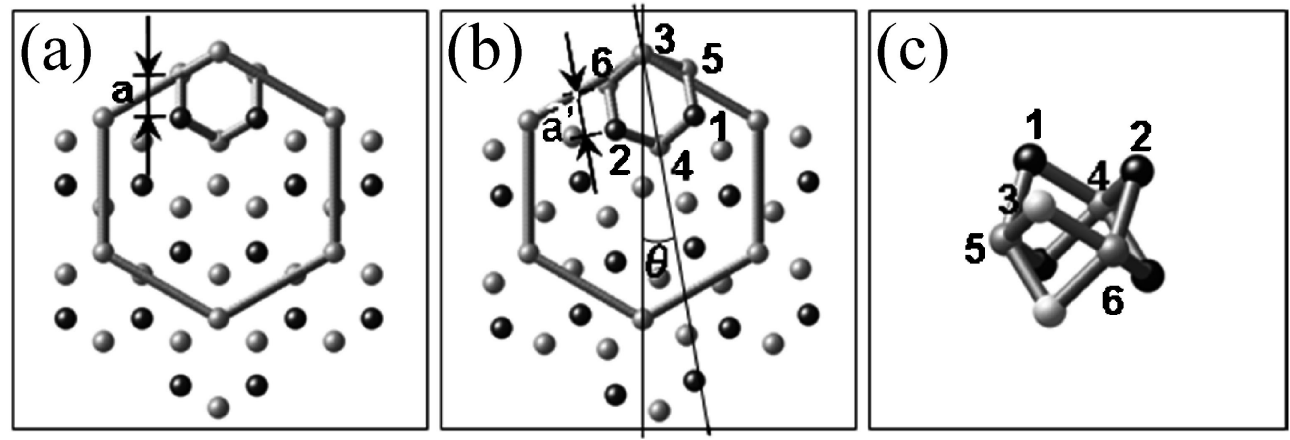

Fig. 5 Crystal structure of $\beta^{\prime}$ phase. (a) Crystal structure reported in a previous study ${ }^{19)}$. (b) Modified crystal structure based on Fig. 2(c). (c) Arrangement of small hexagons in (b).

相の基本の結晶構造として, Fig. 2(d)と（f)に示した HRTEM 像の輝点配列中に見られた大きい正六角形格子と その内側に見られた正六角形副格子の配列の関係に注目し た。まず， $\mathrm{Mg}$ と $\mathrm{Si}$ のみで構成される $\beta^{\prime}$ 相の結晶構造を用 いて, Fig. 5 (a) を基準として, 変化させる正六角形副格子 の大きさ $\left(a^{\prime}\right)$ と，大きい正六角形格子の頂点を回転軸とした 正六角形副格子の回転角 $\theta$ を Fig. 5 (b) に示した. $\theta$ につい ては, $0^{\circ} \sim 30^{\circ}$ まで $5^{\circ}$ 刻及で変化させても, 後の SAED 図形 のシミュレーションに扔いて実駼結果に一致する結果は得ら れなかったので，本報では $10^{\circ}$ 一定と仮定した， $a^{\prime} に$ に拉いて は $a^{\prime}=0.95 a \sim 1.10 a$ まで 0.05 ずつ変化させたシミュレーシ ョンを行い，その結果から 0000 斑点に対する第三近接の $2 \overline{2} 00$ 斑点が弱くなるという実際の SAED 図形と同じ傾向が 見られた $a^{\prime}=1.05 a$ を使用することにした。次に構成元素と して $\mathrm{Mg}, \mathrm{Si}$ 抢よび $\mathrm{Ag}$ の単位胞中での位置を指定するため に,この結晶構造中の原子に Fig. 5 (c) に示したように 1 か ら 6 の番号をつけ，それぞれの位置での原子の占有率を変 化させた. な抢，Fig. 5(c)中の 1〜6は，Fig. 5(b)に扔いて 1 6 と番号をつけた二次元平面上での正六角形に対応す る. 単位胞内での原子位置とそれぞれの位置での原子の占有 率の条件を組反合わせて Table 1 に示したように, model 1 〜 5 を作った. model 1 は $\mathrm{Ag}$ を含まないタイプ，そして
Table 1 Occupancies of atomic positions for five models used in SAED pattern simulations.

\begin{tabular}{|c|c|c|c|c|c|c|}
\hline & \multicolumn{6}{|c|}{ Occupancy of atomic positions } \\
\hline & 1 & 2 & 3 & 4 & 5 & 6 \\
\hline model 1 & $1 \mathrm{Si}$ & $1 \mathrm{Si}$ & $1 \mathrm{Mg}$ & $1 \mathrm{Mg}$ & $1 \mathrm{Mg}$ & $1 \mathrm{Mg}$ \\
\hline model 2 & $1 \mathrm{Si}$ & $1 \mathrm{Si}$ & $1 \mathrm{Ag}$ & $1 \mathrm{Mg}$ & $1 \mathrm{Mg}$ & $1 \mathrm{Mg}$ \\
\hline model 3 & $1 \mathrm{Si}$ & $1 \mathrm{Si}$ & $1 \mathrm{Mg}$ & $\begin{array}{l}0.333 \mathrm{Ag} \\
0.667 \mathrm{Mg}\end{array}$ & $\begin{array}{l}0.333 \mathrm{Ag} \\
0.667 \mathrm{Mg}\end{array}$ & $\begin{array}{l}0.333 \mathrm{Ag} \\
0.667 \mathrm{Mg}\end{array}$ \\
\hline model 4 & $1 \mathrm{Si}$ & $1 \mathrm{Si}$ & $\begin{array}{l}0.75 \mathrm{Ag} \\
0.25 \mathrm{Mg}\end{array}$ & $\begin{array}{l}0.75 \mathrm{Ag} \\
0.25 \mathrm{Mg}\end{array}$ & $\begin{array}{l}0.75 \mathrm{Ag} \\
0.25 \mathrm{Mg}\end{array}$ & $\begin{array}{l}0.75 \mathrm{Ag} \\
0.25 \mathrm{Mg}\end{array}$ \\
\hline model 5 & $1 \mathrm{Si}$ & $1 \mathrm{Si}$ & $\begin{array}{l}0.5 \mathrm{Ag} \\
0.5 \mathrm{Mg}\end{array}$ & $\begin{array}{l}0.875 \mathrm{Ag} \\
0.125 \mathrm{Mg}\end{array}$ & $\begin{array}{l}0.875 \mathrm{Ag} \\
0.125 \mathrm{Mg}\end{array}$ & $\begin{array}{l}0.875 \mathrm{Ag} \\
0.125 \mathrm{Mg}\end{array}$ \\
\hline
\end{tabular}

model 2〜5 は Ag を含むタイプである. Fig. 6 に model 1〜

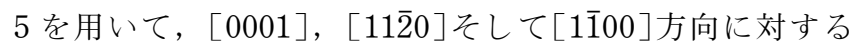
SAED 図形のシミュレーションを行った結果を示す． model 1 は Ag を含まず, 化学組成は先の EDS 分析結果より, $(\mathrm{Mg}+\mathrm{Ag}): \mathrm{Si}=2: 1$ として考元た．基底面の $\mathrm{Mg}$ (3 番)を $\mathrm{Ag}$ と置換したものを model 2, 中間面の $\mathrm{Mg}$ (4〜6 番)を $\mathrm{Ag}: \mathrm{Mg}$ 比を 1:2で置換したものを model 3,すべての $\mathrm{Mg}(3 \sim 6$ 番)を, $\mathrm{Ag}: \mathrm{Mg}$ 比を $1: 3$ で置換したものを model 4 とした。ささらに Ag を基底面と中間面の両方に等分 に入るように, 基底面の 1 個の原子 ( 3 番) は， $0.5 \mathrm{Ag}$ と 


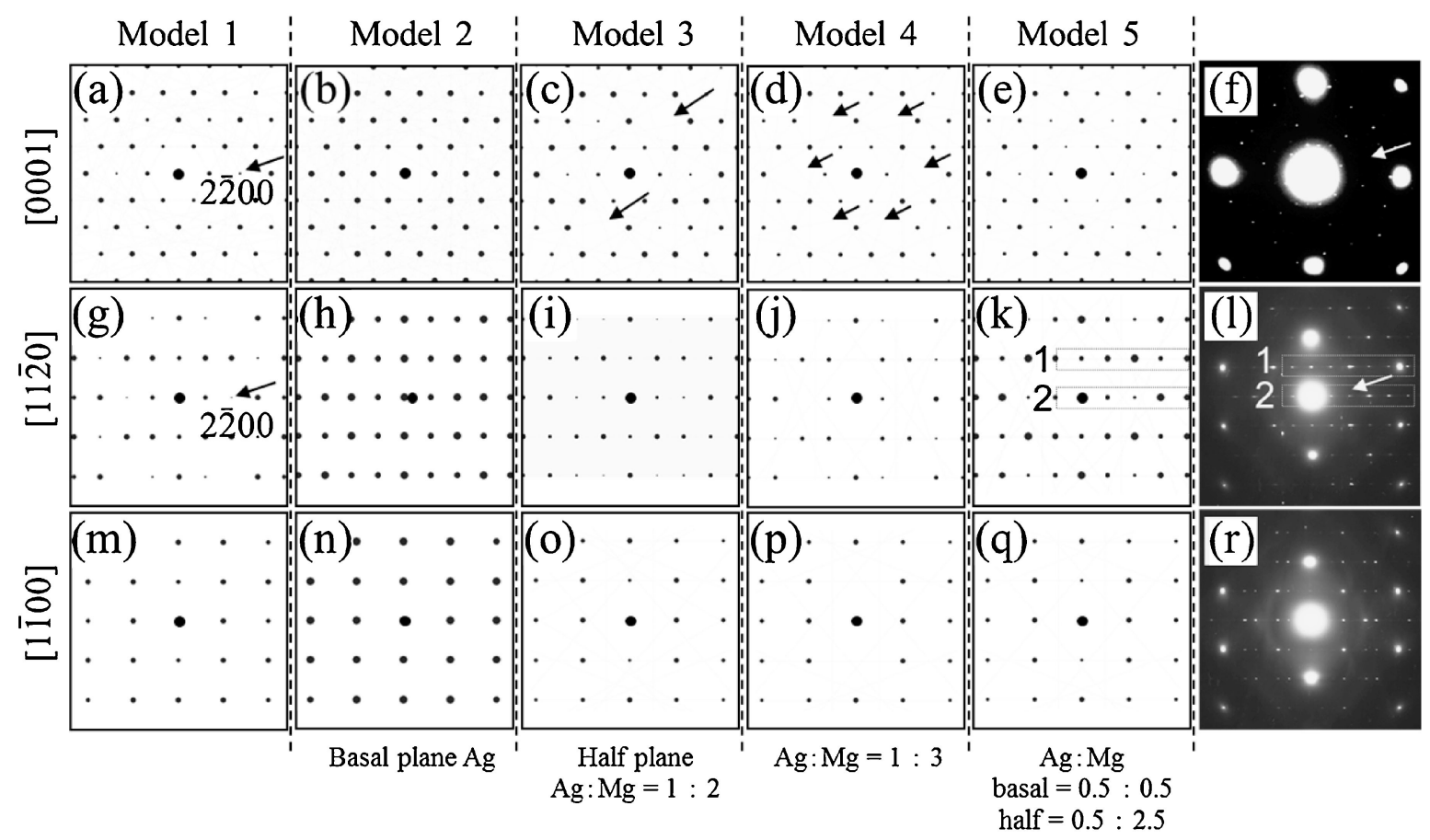

Fig. 6 Summary of simulated SAED patterns using the crystal structure in Fig. (b). The zone axis for (a)-(f) was $[0001]_{\beta^{\prime}}$, for $(\mathrm{g})-(\mathrm{l})$ was $[11 \overline{2} 0]_{\beta^{\prime}}$, and for $(\mathrm{m})-(\mathrm{r})$ was $[1 \overline{1} 00]_{\beta^{\prime}}$. (a), (g), and $(\mathrm{m})$ were obtained using model $1,(\mathrm{~b})$, (h), and (n) using model 2 , (c), (i), and (o) using model 3, (d), (j), and (p) using model 4, and (e), (k), and (q) using model 5.

$0.5 \mathrm{Mg}$ とし，中間面の 3 個の原子 ( $4 \sim 6$ 番) は， 1 原子あた り $0.167 \mathrm{Ag}$ と $0.833 \mathrm{Mg}$ を含むようにしたものを, model 5 とした.Fig. 6(f)，(1)，(r)に示した実際の SAED 図形から は下記の特徵がみられるので，それらを満たすシミュレーシ ョン像が最も実際のSAED 図形と一致することになる.

(1) [0001]方向に対するSAED 図形においては，第三近 接の $2 \overline{2} 00$ 斑点が弱い.

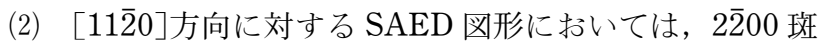
点が弱く, かつ 0001 斑点, $2 \overline{2} 01,3 \overline{3} 00$ 打よび $4 \overline{4} 00$ 斑点が 強い.

(3) [1100]方向に対するSAED 図形に抢いては，回折斑 点の強度に大きな違いがない，

まず Ag を含まない model 1 の Fig. 6(a)において, 図中 に矢印で示したように，0000 斑点に対する第三近接の $2 \overline{2} 00$ 斑点が弱くなるという実際の SAED 図形と同じ傾向が見ら れた．他の二つの方位については，とくに[1120̄0]に対する 回折図形に扔いて， $2 \overline{2} 00$ 斑点が弱くなる，Fig. 6(1)の実像 との良い一致が得られた．Ag を含むモデルに注目すると， [0001]方向に対する SAED 図形では, model 2 の(b) は強度 に差がなく, model 3 の(c)では矢印に示した部分の回折斑 点の反が非対称に消えて抢り，対称性が崩れて実際の SAED 図形々一致しない. model 4 の (d)では $2 \overline{2} 00$ 系の回 折斑点が完全に消えてしまっている．そして model 5 の(e) では， $2 \overline{2} 00$ 斑点が消えず弱い回折として現れており，実際 のSAED 図形と一致した。そこで model 5 に注目し，Fig. $6(1)$ に打ける $[11 \overline{2} 0]$ 方向から得られた実際の SAED 図形中 に白枠で囲った領域と, Fig. 6(k)のシミュレーションした SAED 図形中の黑枠で囲った領域における回折斑点の強度 プロファイルを，Fig. 7 にて比較した. Fig. 7 (a)に示した
ように，実際の SAED 図形では 0001 斑点と $2 \overline{2} 01$ が強く, また Fig. 7 (b)では $2 \overline{2} 00$ 斑点が弱く, $3 \overline{3} 00$ および $4 \overline{4} 00$ 斑 点が強い，この特徵は，Fig. 7(i) 打よび $(\mathrm{j})$ に打いてもよく 一致していた。したがって， $\beta^{\prime}$ 相の結晶構造としては，Fig. 5 (b)に示したように， $0.69 \mathrm{~nm}$ の単位胞と，その正六角形の 頂点を回転軸とした $0.24 \mathrm{~nm}$ の副格子を基本として, $\mathrm{Mg}$ ： $\mathrm{Si}: \mathrm{Ag}$ 比が $3: 2: 1$ で，かつ基底面と中間面にはそれぞれ $\mathrm{Mg}$ と $\mathrm{Ag}$ が $50 \%$ ずつ，中間面の 3 個の原子は， 1 原子あた り $16.7 \%$ の $\mathrm{Ag}$ と $83.3 \%$ の $\mathrm{Mg}$ を含むように原子散乱因子 を計算した, model 5 が最も一致すると考えられる.

そこでこの model 5 の妥当性を確認するため, 母相の方 位から $\beta^{\prime}$ 相を観察して得られた HRTEM 像と, model 5 を 用いて計算した HRTEM 像のシミュレーション結果を Fig. 8 にて比較した。（a)〜 (e)が実像， (f) 〜 (j) が model 5 を用 いて計算した HRTEM 像のシミュレーション結果, そして (k)〜 (o) が model 5 を各方位から投影した模式図である. 観察方向はそれぞれ棒状析出物の断面方向である[0001]方 向，長手方向に垂直な㑯面方向である $[1 \overline{1} 00]$ と $[11 \overline{2} 0]$ 方 向，さらに長手方向に垂直な㑯面方向と断面方向との間で長 手方向に垂直な方向に対して斜め方向となる $[2 \overline{2} 03]$ と [112̄1]方向である. 例えば Fig. 8(h)にみられる $\{4 \overline{4} 00\}$ 面の 間隔 $0.19 \mathrm{~nm}$ と, Fig. 8 (i) に観察される $\{3 \overline{3} 02\}$ 面の間隔 $0.14 \mathrm{~nm}$ は, Fig. 8 (c) と (d)に示した実際の HRTEM 像で もとれぞれ観察されている，以上の結果から，実際に得られ た HRTEM 像とシミュレーション像は，推察される投影像 とも良い一致を示して打り，先の仮定で得られた model 5 は妥当であると考えられた。

さらに $\beta^{\prime}$ 相の中に $\mathrm{Ag}$ が固溶する構造が妥当であるのかを 離散变分局所密度近似クラスタ (Discrete Variational (DV- 


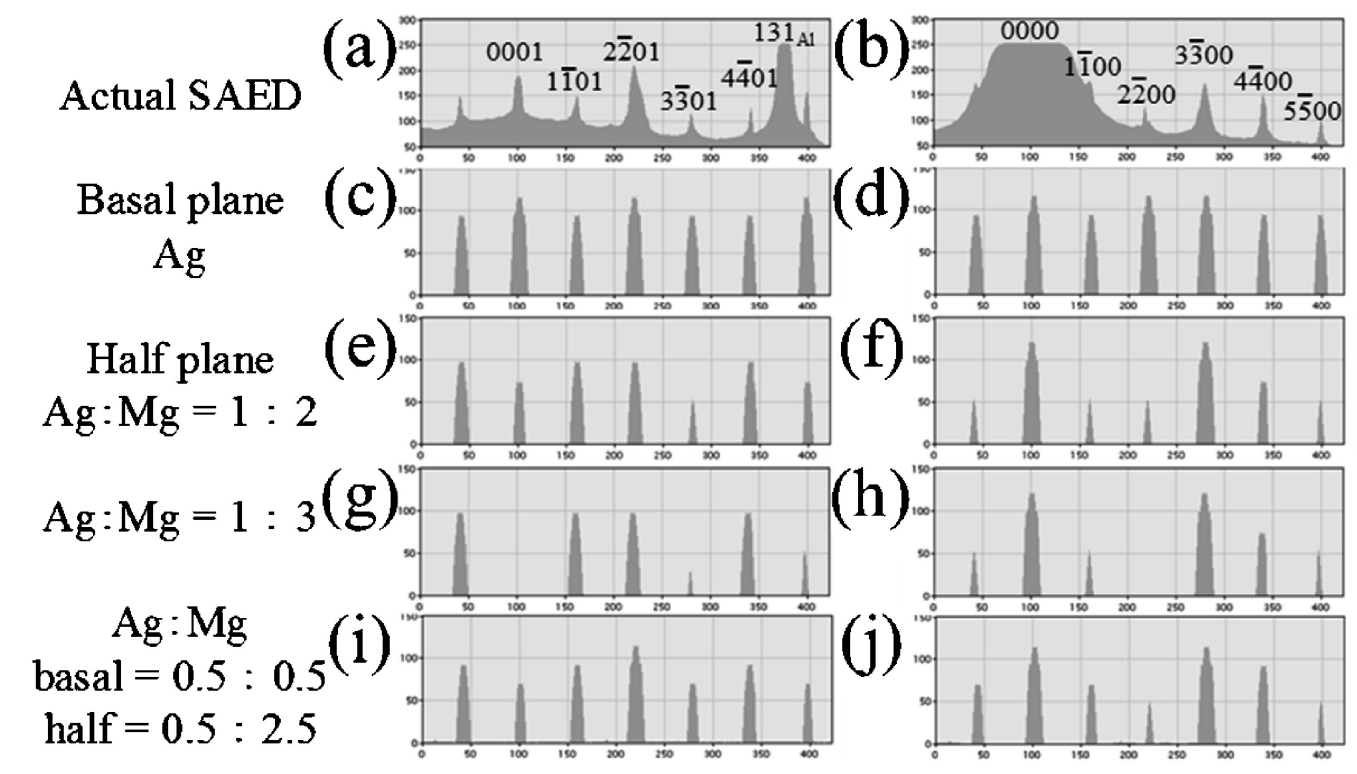

Fig. 7 Line profiles obtained from SAED patterns and simulations. (a) and (b) obtained for regions 1 and 2 in SAED patterns in Fig. 6(1). (c) and (d) correspond to model 2, (e) and (f) to model 3, (g) and (h) to model 4, and (i) and (j) to model 5. (c), (e), (g), and (i) correspond to region 1 in Fig. $6(1)$, and (d), (f), (h), and (j) correspond to region 2 in Fig. 6 (1). The left column indicates the chemical ratio of $\mathrm{Ag}$ and its position.

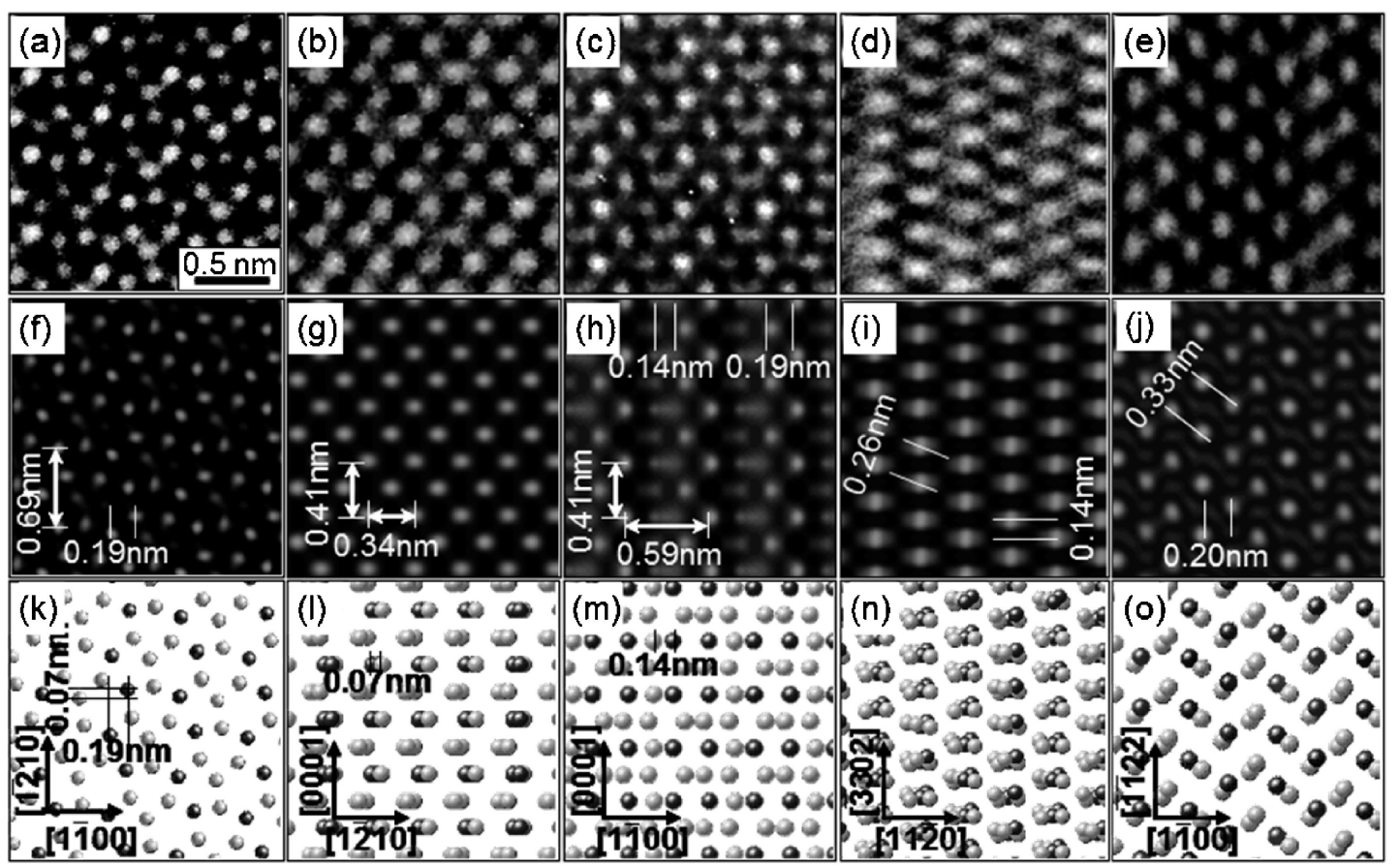

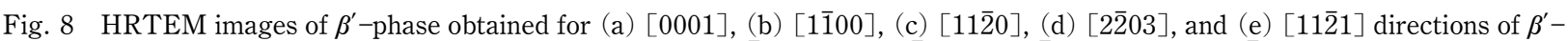
phase. Corresponding simulated images for (f) $[0001],(\mathrm{g})[1 \overline{1} 00]$, (h) $[11 \overline{2} 0]$, (i) $[2 \overline{2} 03]$, and (j) $[11 \overline{2} 1]$ directions of $\beta^{\prime}$-phase,

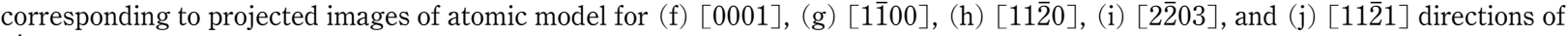
$\beta^{\prime}$-phase.

$\mathrm{X} \alpha)$ )法を用いて検討した ${ }^{23)}$. DV-X $\alpha$ における有効共有結合 電荷 (Bond Overlap population (BOP))の計算に使用したク ラスタの模式図を Fig. 9 に示す. Fig. $9(\mathrm{a})$ は $\beta^{\prime}$ 相の〈0001〉 投影の模式図であり, Fig. 5(b)に示した SAED 図形の計算 に使用した結晶構造モデルから，BOP 計算に使用するため の原子間の結合を考慮したクラスタモデルを示している.

Fig. 9 (a)中に示した M の原子位置は基底面内に存在する $\mathrm{Mg}$ 原子の位置であり，この原子を $\mathrm{Ag}$ と置換する. 計算に
は Fig. 9(a) 中に示したこの M の原子位置を中心として, Fig. 9(b)に示すように $\mathrm{Mg}, \mathrm{Si}$ そして $\mathrm{M}(=\mathrm{Mg}, \mathrm{Ag})$ 原子の 数の和が 19 個となる第 6 近接までの原子を使用した $\mathrm{M}_{1}$ $\mathrm{Mg}_{12} \mathrm{Si}_{6}$ クラスタを使用した。な抢このクラスタは，Fig. 9 (a)中の実線で示した部分に相当する. 第 1 近接の原子間を 実線で，第 2 近接以降を両矢印のついた実線，破線または 点線で示した。第 2 近接を太い実線，第 3 近接を細い実 線，第 4 近接を太い破線，第 5 近接を二重線，第 6 近接を 

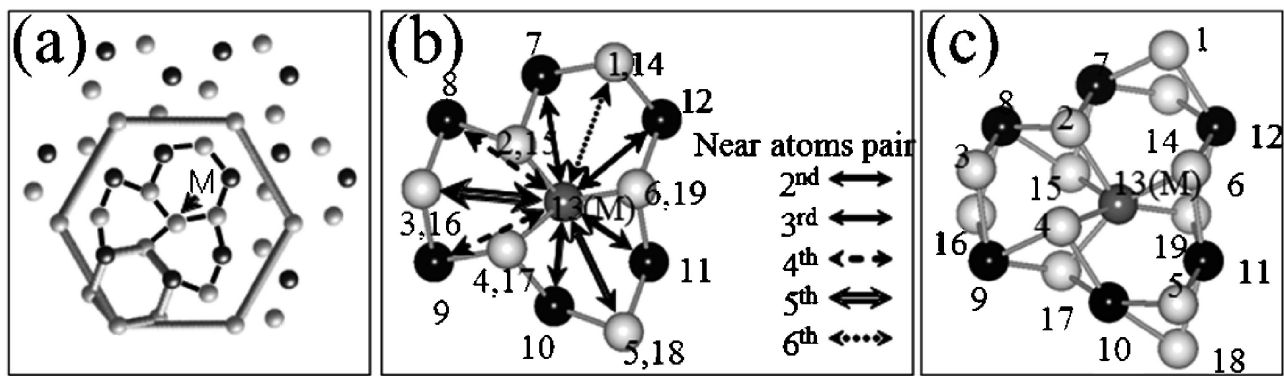

Fig. 9 Cluster model of crystal structure of $\beta^{\prime}$-phase determined by DV-X $\alpha$ calculations.

点線で示している.クラスタの化学組成は, 実験で得られた 析出物の化学組成の結果に基づくと, $(\mathrm{Mg}+\mathrm{M}) / \mathrm{Si}$ 比は 2 になるが， $\mathrm{M}_{1} \mathrm{Mg}_{12} \mathrm{Si}_{6}$ クラスタでは $(\mathrm{Mg}+\mathrm{M}) / \mathrm{Si}$ 比は 2.2 となる。な抢，Fig. 9 (c) は原子の位置関係を示すために Fig. 9(b)を手前に $20^{\circ}$ 傾けた図である. Fig. 9(b) と (c)にお いて, 図中の 1 19の数字は, クラスタ中の原子を示して いる. 1〜6, 7〜13, 14〜19がそれぞれ同じ結晶面上に存在 する原子位置である. 今 13 番の中心原子 $\mathrm{M}$ に対して, 第 1 近接は 13 番の原子と 2 番または 15 番, 13 番の原子と 6 番 または 19 番, そして 13 番の原子と 4 番または 17 番の 6 つ の組合せであり，その原子間距離は $0.31 \mathrm{~nm}$ である. 同様 に第 2 近接，第 3 近接についてまとめたものを Table 2 に 示した. Fig. 9(b) からも明らかなように，このクラスタを [0001]方向から二次元投影すると, 13 番， 2 番 (または 15 番), 7 番， 1 番 (または 14 番)，12 番，6 番(または 19 番) の原子のつながりで示される正六角形と， 13 番， 6 番(また は 19 番)，11 番， 5 番(または 18 番)，10 番，そして 4 番 （または 17 番)，さらに 13 番， 4 番 (または 17 番)，9 番， 3 番(または 16 番), 8 番, 2 番(または 15 番)で示される $2 つ$ の歪んだ六角形が組み合わさった形態として示されている. ここで著者らが仮定している $\beta^{\prime}$ 相の結晶構造において，7〜 13 番が基底面, $1 \sim 6$ 番と $14 \sim 19$ 番が中間面に存在し, $\mathrm{Ag}$ との置換を考えない場合， 1 6 番と 14〜19 番は $\mathrm{Mg}$ で， 7 $\sim 12$ 番は $\mathrm{Si}$ となる. BOP の結果はそれぞれ $\mathrm{M}-\mathrm{Si}, \mathrm{M}-\mathrm{Mg}$ および $\mathrm{Mg}-\mathrm{Si}$ の結合に対する平均の BOP を Table 3 に示し た．どの結合の BOP の值にも大きな変化は見られず，Mg を $\mathrm{Ag}$ と置換しても共有結合の程度はほぼ同じになることを 示唆していると考えられた．また，以前著者らのグループが 行った $\mathrm{fcc}-\mathrm{Al}$ の最小単位である正四面体クラスタを用いた 計算では, $\mathrm{Mg}$ と $\mathrm{Ag}$ が $\mathrm{Mg}, \mathrm{Al}$ あるいは $\mathrm{Si}$ との結合におい て類似の BOP 值を示すという結果を得て抢り，今回の計算 結果と一致した ${ }^{24)}$. したがって, Fig. 6 と Fig. 7 で示した SAED 図形のシミュレーションに打いて，各 Mg 原子に対 して異なる占有割合で $\mathrm{Ag}$ を置換する方法は妥当であると考 えられた。

また，Ag 添加した本系合金における析出物の微細化に関 する報告, DSC 測定での GPゾーンあるいはクラスタに対 する $\mathrm{Ag}$ の関与に関する報告14)を考元合わせると, 中間相に $\mathrm{Ag}$ が構成原子として含まれる, あるいは固溶しているとい うことは, 合理的であると考えられる。ささらに Cu添加した 本系合金と同様の $\mathrm{Q}^{\prime}$ あるいは $\mathrm{Q}$ 相のような析出が母相中で
Table 2 Interatomic spacings of first to sixth nearest neighbor atoms in Fig. 9 (b).

\begin{tabular}{ccc}
\hline Near atoms & Atomic spacing & Atoms pair \\
\hline 1st & 0.31 & $13-(2,15), 13-(6,19), 13-(4,17)$ \\
\hline 2nd & 0.33 & $13-10,13-11$ \\
\hline 3rd & 0.41 & $13-12,13-7$ \\
\hline 4th & 0.46 & $13-8,13-9$ \\
\hline 5th & 0.5 & $13-(3,16), 13-(5,18)$ \\
\hline 6th & 0.51 & $13-(1,14)$ \\
\hline
\end{tabular}

Table 3 BOP calculation results using the cluster in Fig. 9 (c). Substitutional atoms $(\mathrm{M})$ represent the atom labeled $13(\mathrm{M})$ in Fig. 9 (c).

\begin{tabular}{cccc}
\hline \multirow{3}{*}{ Bonding } & & \multicolumn{2}{c}{ Substitutional atoms } \\
\cline { 3 - 4 } & & $\mathrm{Mg}$ & $\mathrm{Ag}$ \\
\hline \multirow{3}{*}{} & $\mathrm{M}-\mathrm{Si}$ & 0.140 & 0.133 \\
\cline { 2 - 4 } & $\mathrm{M}-\mathrm{Mg}$ & 0.201 & 0.212 \\
\cline { 2 - 4 } & $\mathrm{Mg}-\mathrm{Si}$ & 0.246 & 0.235 \\
\hline
\end{tabular}

起こるか否かについては，本研究では明らかにはできなかっ た。しかし，既報にて結晶粒界上には Q 相と同様の結晶格 子を持つ析出物を確認していることから，今後詳細に調べて 検討する必要がある。

\section{5. 結 言}

$523 \mathrm{~K}$ で時効した $\mathrm{Al}-0.94$ mass\% $\mathrm{Mg}_{2} \mathrm{Si}-0.55$ mass\% $\mathrm{Ag}$ 合金に析出する $\beta^{\prime}$ 相を HRTEM 観察し, 添加した $\mathrm{Ag}$ の結 晶構造に及ぼす影響について調べた。得られた結果を要約す ると以下のとおりである.

(1) Ag 添加合金を $523 \mathrm{~K}$ に抢いて $120 \mathrm{ks}$ まで時効した 結果では, $\mathrm{Ag}$ を添加していない基合金に見られる典型的な $\mathrm{Al}$ 母相の $\langle 100\rangle$ 方向に沿って伸びる棒状の $\beta^{\prime}$ 相が観察され た. $\mathrm{Cu}$ 添加とは異なり析出した第二相はほぼ $\beta^{\prime}$ 相であり, 今回の観察では $\mathrm{Q}-\mathrm{AlMgSiCu} 4$ 元系化合物に対応する AlMgSiAg4 元系化合物は母相中の析出組織には観察されな かった.

(2) Ag 添加合金で観察された $\beta^{\prime}$ 相より得られた EDS 分 析の結果では $\mathrm{Mg}, \mathrm{Si}$ ，および $\mathrm{Ag}$ が検出された。また, 観 察された $\beta^{\prime}$ 相の格子定数の $a$ 軸は基合金に見られるそれと 
比較して小さくなっていた.

(3) $\beta^{\prime}$ 相から得られた HRTEM 像中には 1 辺が $0.69 \mathrm{~nm}$ の大きい六角形とそれに対して $10^{\circ}$ 傾いた $0.24 \mathrm{~nm}$ の小さな 六角形を持つ輝点配列が見られた。これは $\mathrm{Ag}$ を含まない合 金中の $\beta^{\prime}$ 相にも共通にみられる特徵であった.

(4) Ag を含む合金中の $\beta^{\prime}$ 相の結晶格子として, 結晶構造 の中に見られる一辺が $0.235 \mathrm{~nm}$ の六角形を基準として $10^{\circ}$ 回転させ，さらにその間隔を $105 \%$ に広げた $0.24 \mathrm{~nm}$ の構造 モデルを用いることで, 実際の SAED 図形とシミュレーシ ョン結果とに良い一致が見られた.さらに $\beta^{\prime}$ 相の結晶構造 中の $\mathrm{Ag}$ の位置としては，基底面と中間面に $50 \%$ ずつ，そ して中間面の 3 個の原子は 1 原子あたり $16.7 \%$ の $\mathrm{Ag}$ と 83.3\%の Mg を含むように原子散乱因子を計算した構造を用 いると，実際に得られた SAED 図形および HRTEM 像と， それらのシミュレーション結果でよい一致が見られた。

(5) EDS 分析, 測定された析出物の格子定数, DV-X $\alpha$ を 用いた BOP の計算から中間相に $\mathrm{Ag}$ が構成原子として含ま れる，あるいは固溶している可能性が示唆された。

本研究の一部は富山大学ベンチャービジネスラボラトリー 2007-2009 プロジェクト研究として行われた. 合金の化学 組成分析にご協力いただいた新日軽秼北陸製造所技術課の皆 様に謝意を表する。

文献

1) K. Obori: Structures and Properties on Aluminum Alloys, (Japan Institute of Light Metals, 1991) pp. 278-295.

2) D. J. Chakrabarti and D. E. Laughlin: Prog. Mater. Sci. 49
(2004) 389-410.

3) S. D. Dumolt, D. E. Laughlin and J. C. Williams: Scr. Metall. 18 (1984) 1347

4) D. J. Chakrabarti, B.-K. Cheong and D. E. Laughlin: Automotive Alloys II, (TMS, 1998) pp. 27-44.

5) D. E. Laughlin, W. F. Miao, L. M. Karabin and D. J. Chakrabarti: Automotive Alloys II, (TMS, 1998) pp. 63-79.

6) C. Cayron, L. Sagalowicz, O. Beffort and P. A. Buffat: Philos. Mag. A 79(1999) 2833-2851.

7) C. Cayron, P. A. Buffat, O. Beffort and S. Long: J. Mater. Sci. 34 (1999) 905-915.

8) C. Cayron and P. A. Buffat: Acta Mater. 48(2000) 2639-2653.

9) V. Massardier, T. Epicier and P. Merle: Acta Mater. 48(2000) 2911-2924.

10) C. D. Marioara, S. J. Andersen, A. Birkeland and R. Holmestad: J. Mater. Sci. 43(2008) 4962-4971.

11) J. Polmear: Trans. Metall. AIME 230(1964) 1331-1339.

12) Y. Baba and A. Takashima: Technical Reports of Sumitomo Light Metals 10 (1969) 1-11.

13) T. Maeguchi, K. Yamada and T. Sato: J. Japan Inst. Metals 66 (2002) 127-130.

14) A. Gager, K. Matsuda, A. Ali, Y. Zou and S. Ikeno: Mater. Sci. Technol. 20 (2004) 1627-1631.

15) K. Matsuda, Y. Sakaguchi, Y. Miyata, Y. Uetani, T. Sato, A. Kamio and S. Ikeno: J. Mater. Sci. 35 (2000) 179-189.

16) K. Matsuda, S. Ikeno, T. Sato and Y. Uetani: Scr. Mater. 55 (2006) $127-129$.

17) J. Nakamura, K. Matsuda, T. Kawabata, T. Sato, Y. Nakamura and S. Ikeno: Mater. Trans. 51(2010) 310-316.

18) K. Matsuda, H. Gamada, K. Fujii, T. Yoshida, T. Sato, A. Kamio and S. Ikeno: J. JILM 47(1997) 493-499.

19) K. Matsuda, S. Tada and S. Ikeno: J. Japan Inst. Metals $\mathbf{5 7}$ (1993) $1107-1113$.

$20)$ D. Shindo and K. Hiraga: High Resolution Transmission Microscopy for Materials Analysis, 1st ed., (Sankyo Shuppan, Tokyo, 1996) pp. 19-40.

21) G. Cliff and G. W. Lorimer: J. Microscopy 103(1975) 203.

22) M. H. Jacobs: J. Inst. Metals 90(1961-62) 57.

23) H. Adachi, Y. Owada, I. Tanaka, H. Nakamatsu and M. Mizuno: Introduction of $D V-X \alpha$ Method, 3rd ed., (Sankyo Shuppan, Tokyo, 2001).

24) K. Matsuda, S. Ikeno, T. Sato and Y. Uetani: Scr. Mater. 55 (2006) 127-129. 